\title{
STAFF MOTIVATION PROBLEMS IN SMALL ENTERPRISES
}

\author{
Iluta Arbidane1, Dairis Arbidans², Evalds Viskers ${ }^{3}$, \\ Iveta Graudina ${ }^{4}$ \\ ${ }^{1}$ Dr.oec., professor, leading researcher, Rezekne Academy of Technologies, Rezekne, \\ Latvia, e-mail: Iluta.Arbidane@rta.lv \\ 2Student at Master of Management program, Rezekne Academy of Technologies, \\ Rezekne, Latvia, e-mail: Dairis.Arbidans@inbox.lv \\ ${ }^{3}$ Mg.soc.sc., lecturer, researcher, Rezekne Academy of Technologies, Rezekne, Latvia, \\ e-mail: Evalds.Viskers@rta.lv \\ ${ }^{4}$ Mg.soc.sc., lecturer, Rezekne Academy of Technologies, Rezekne, Latvia, \\ e-mail: Iveta.Graudina@rta.lv
}

Received: 14 October 2020 / Revised: 25 October 2020 / Accepted: 10 November 2020 / Published: 30 November 2020

\begin{abstract}
One of the challenges a company manager constantly faces is employee motivation. According to the authors' empirical experience, in small enterprises, an entrepreneur often has limited opportunities to hire a large number of employees, so the existing ones have to perform not only direct job responsibilities within their positions or professions, but also other additional duties. The aim of the research is to study the problems and opportunities of employee motivation in small enterprises. Two surveys were conducted to achieve the aim. The survey of entrepreneurs examined the motivation of employees from the point of view of entrepreneurs, while the second survey examined the opinion of employees on motivation in small enterprises. As a result, the motivators were ranked from both points of view and compared.
\end{abstract}

Keywords: small enterprises, motivation, personnel.

JEL code: M12.

\section{Introduction}

Personnel management is one of the most important functions of company management that considers a person as the only source of creativity and creative expression, thus being a cornerstone of organizational development and the most important and valuable resource of the company. This is especially important for small businesses. Employee motivation is one of current problems and also the biggest challenge for a company manager. According to the authors' empirical experience, in small companies, an entrepreneur often has limited opportunities to hire a large number of employees, so the existing ones have to perform not only job responsibilities within their positions or professions, but also other additional duties. Small businesses have limited resources and the entrepreneur cannot always afford to pay adequate salaries. These and other factors affect employee 
motivation. The daily life of an entrepreneur is continuous work with employees.

The research problem: small business managers will face major challenges regarding the company's personnel in the future. Small businesses in particular have much more limited opportunities to attract technology, finance and excellent staff, while they are more flexible in responding to changes in the external and internal environment. Employees create the company's operating results, often with limited resources. In order to retain employees, a special challenge for a manager is to keep and maintain employees' motivation.

The research aim is to study the problems of and possibilities for employee motivation in small companies.

The research tasks:

1) to study the concept and nature of motivation, motivation theories and factors influencing motivation in small enterprises;

2) to analyse the peculiarities of employee motivation in small enterprises from the point of view of entrepreneurs;

3) to study the peculiarities of employee motivation in small enterprises from the point of view of employees.

Hypothesis: Salary is the determining motivator of employees in small companies.

In order to achieve the aim, the following research methods were used: the monographic analysis method, statistical research methods - grouping, comparison, analysis, ranking, the graphical method, the sociological research method - a survey. The area of empirical study - Latgale region.

The novelty of the research is formed by the surveys conducted within the research. The survey of entrepreneurs examined the motivation of employees from the point of view of entrepreneurs, while the second survey examined the opinion of employees on motivation in small companies. As a result, the motivators were ranked from both points of view and compared.

Period of research: 2015 - 2019.

\section{Peculiarities of application of motivation as a management element in small enterprises}

In most countries of the world, small and medium-sized enterprises account for a significant share of total GDP in all sectors of the economy, both in the production of goods and in the provision of services. Small businesses solve employment problems and ensure development at the regional level. As Ordynskaya points out, small and medium-sized enterprises influence national growth rates. Analysing the economic indicators of the largest economies, the authors conclude that in developed countries small and 
medium-sized enterprises account for about $60-70 \%$ of national GDP (Ordynskaya, 2016). According to European Commission Regulation No.651/2014, micro, small and medium-sized enterprises (SMEs) are commercial entities that meet the specified indicators: number of employees, turnover, and balance sheet total. The company's staff consists of:

- employees,

- owner-managers,

- persons working for the enterprise being subordinated to it and deemed to be employees under national law,

- partners engaging in a regular activity in the enterprise and benefiting from financial advantages from the enterprise.

The peculiarities of small business management have always interested researchers. Looking at the basic principles of small business management, one of the most relevant stages of management is resource management.

The company's resource approach has been studied by J. B. Barney (Barney, 1991). According to Barney's approach, the company's resources must be valuable, rare, irreplaceable and difficult to imitate. The researcher argues that entrepreneurs often focus on attracting and managing external resources, neglecting the potential of internal resources, including both their own entrepreneurial skills and the potential of their employees. Most often, the owner of the company is also the manager of the company, who manages the company from the point of view of the value of his property and focuses on the management of material resources.

Barney and Arikan (Barney, Arikan, 2001) divide a company's resources into two parts: tangible and intangible. If we look at personnel management, then it is understandable that it is the personnel and the entrepreneur himself that are intangible resources that require a special approach. Researchers such as Eriksen and Mikkelsen (Eriksen, Mikkelsen, 2006), Ray, Barney, and Muhhana (Ray, Barney, Muhanna, 2004) also highly value entrepreneurial and staff abilities as intangible resources.

In her dissertation, Kantāne concludes that less research has been done on how to run a small company, what a small company manager should be in order for a company to operate successfully. Small business management and development has been addressed by Leon Meginson, Mary Byrd, William Megginson, Charles Kuehl, Peggy Lambing, Fuller-Love, and others (Kantāne, 2013).

Historically, both in Latvia and elsewhere in the world, it has developed that the manager of a small company is also the owner of the company. It is natural that a person with his knowledge and skills wants to build a business and earn money by providing for himself and his family. Consequently, a small business organization is characterized by an approach of private owner. 
The authors believe that the organization of a small business is significantly influenced by the level and field of education of the owner/manager. This empirical experience is also confirmed by book authors and researchers. Megginson and other authors emphasize that it is important for every entrepreneur to learn the basics of running a business in order to avoid the risk of incompetent management (Megginson, Byrd, 2005).

The role of employees in the successful operation of companies is repeatedly emphasized in scientific research. Tobassi and others argue that staff capacity plays an important role in the organizational success of a small business. The authors of the research prove that the greatest contribution to success is made by training, motivation, and team spirit (Tabassi, Ramli, Bakar, 2012). Jorfi et al. emphasize motivation, effective communication and emotional intelligence as the most important basis for the success of an organization in small companies (Jorfi, Yaccob, Shah, 2011). As another important criterion for the successful development of an organization, the authors point out the strategic vision and its purposeful fulfillment. It acts as an important motivator for the manager and also for employees who clearly understand the direction of the company's activities. It gives employees the desire to develop to meet the company's goals.

Maccdonald et al. (Maccdonald, Assimakopoulos, Anderson, 2007) in their study prove that the competitiveness and innovative activities of small companies are promoted by the education and continuous development of the entrepreneur and his employees. Based on the former research, the authors conclude that the management of a small company differs from the management processes in large companies, where each of the organizational units is managed by knowledgeable employees, while the challenge of small company management is to accumulate and develop extensive knowledge in particular and specific areas of activity.

Employee motivation today is one of the most actual concepts discussed in relation to the company's personnel management. As technology opportunities, labour migration, people's education and employment opportunities increase, motivation becomes a key word in attracting and retaining a quality workforce.

According to Vorončuka, the staff consists of people with their work, hopes, goals, needs and problems in the organization (Vorončuka, 2009). It follows that an employee in a company is both an individual and a resource of the company.

In the motivation process, employees choose one of the action alternatives to achieve personal goals. The goals that people strive for can be tangible - money, promotion, as well as abstract - self-esteem, job satisfaction. The remuneration that a particular employee could receive is 
divided into internal and external. Internal remuneration is derived from each person's personal experience (self-esteem); external remuneration is granted from the outside (benefits, promotion) (Bel̦čikovs, Praude, 2001). Business managers are interested in achieving harmony between employees and company goals, which affects motivation.

Reviewing the above mentioned concepts, the authors have created a table summarising main elements motivation theories.

\section{Table 1. Motivation theories, explanation of their essence}

$$
\text { (compiled by the authors) }
$$

\begin{tabular}{|c|c|}
\hline $\begin{array}{l}\text { Motivation theory } \\
\text { and its } \\
\text { representatives }\end{array}$ & Essence \\
\hline $\begin{array}{l}\text { Pyramid of needs or } \\
\text { theory of hierarchy } \\
\text { of needs (1954) } \\
\text { A. H. Maslow }\end{array}$ & $\begin{array}{l}\text { Individual needs exist in a hierarchical order (physiological, security, } \\
\text { social affiliation, social recognition (self-esteem) and self- } \\
\text { expression). Every level of needs is a motivating factor for employees, } \\
\text { if it is not met. The employee is motivated by the needs of the higher } \\
\text { level, satisfying the lower ones first. }\end{array}$ \\
\hline $\begin{array}{l}\text { ERG theory } \\
\text { C. Alderfer }\end{array}$ & $\begin{array}{l}\text { Motivation coexists in the need for existence, commitment or kinship, } \\
\text { and growth. They have no established order or transition from one } \\
\text { level to another. Each of the needs can be relevant in parallel. }\end{array}$ \\
\hline $\begin{array}{l}\text { Three Needs Theory } \\
\text { (1967) } \\
\text { D. McClelland }\end{array}$ & $\begin{array}{l}\text { People acquire and become aware of their needs during life through } \\
\text { experience: belonging/ communication, power and success. They are } \\
\text { not biologically inherited and depend on the environment, } \\
\text { conditions, etc. }\end{array}$ \\
\hline $\begin{array}{l}\text { Two Factor Theory } \\
\text { (1950ies) } \\
\text { F. Herzberg }\end{array}$ & $\begin{array}{l}\text { There are two groups of motivators - hygiene factors and motivation } \\
\text { factors. Needs that are hygiene factors do not motivate, but create job } \\
\text { satisfaction. When one of them is missing, there is dissatisfaction with } \\
\text { the job. The motivation factor guarantee provides higher work } \\
\text { motivation. }\end{array}$ \\
\hline $\begin{array}{l}\text { Equity theory } \\
\text { (1963) } \\
\text { J. S. Adams }\end{array}$ & $\begin{array}{l}\text { People compare the efforts and rewards they receive with the efforts } \\
\text { and rewards of other people. Perceived inequality has a negative } \\
\text { effect on motivation (for example, by reducing work effort or } \\
\text { demanding more compensation). }\end{array}$ \\
\hline $\begin{array}{l}\text { Expectancy Theory } \\
\text { (1964) } \\
\text { V. Vroom }\end{array}$ & $\begin{array}{l}\text { A person is motivated to choose a particular pattern of behaviour if } \\
\text { there is a possibility that the effort will improve the result of the } \\
\text { work. In turn, it will provide a higher salary and satisfaction of } \\
\text { received. }\end{array}$ \\
\hline $\begin{array}{l}\text { Goal Setting Theory } \\
\text { (1990) } \\
\text { E. Locke, G. Latham }\end{array}$ & $\begin{array}{l}\text { Motivation is affected by how important, specific and complex are } \\
\text { goals of each individual. The higher level they are, the higher is the } \\
\text { motivation. Employees are demotivated by vaguely defined, simple } \\
\text { and easily achievable goals. }\end{array}$ \\
\hline $\begin{array}{l}\text { Job characteristics } \\
\text { model (1976.) } \\
\text { R. Hackman, } \\
\text { G. Oldham }\end{array}$ & $\begin{array}{l}\text { Motivation is created by the environment in which the employee is } \\
\text { located. The task of the manager is to find an opportunity to organize } \\
\text { the work process so that it creates work motivation. It can be built } \\
\text { through a variety of skills, work intensity, feedback, etc. }\end{array}$ \\
\hline
\end{tabular}


As we can see from the above mentioned, there are many theories of motivation, they are different and not perceived unambiguously, because at any given moment, the employee's motivation can change in a different way, when influenced by these or other factors. The authors believe that in current conditions, when Latvia is constantly experiencing a process of change both in the global aspect and at the national and company level, the use of theories can be assessed subjectively. It is important to take into account each individual's personality traits, level of development, professional and intellectual level, including occupation, environment, economic and social conditions.

\section{Analysis of motivation implementation in small enterprises}

The authors have conducted a study with the aim of finding out the opinion of small business employees and managers on the motivational aspects of the company. Two surveys were conducted during the study. One of the questionnaires was handed out to entrepreneurs and the other - to employees.

Both surveys focused on employees' motivation and the evaluation of motivators, but from different points of view. Namely, how this research object is seen and perceived by the company's management and how - by the employees themselves.

Entrepreneurs whose companies were located in Latgale region were surveyed. Forty questionnaires were distributed, of which 18 were returned. The questionnaires were distributed both electronically and in person by visiting entrepreneurs. As a result, the authors conclude that entrepreneurs do not participate in surveys reluctantly, on the pretext of busyness and unwillingness to get involved. Eighteen questionnaires were completed in person by visiting entrepreneurs, and most often they were acquaintances.

The survey of small business managers asked to evaluate motivators that are used in relation to employees. Several answers were allowed, which are summarized in Figure 1.

As we can see in Figure 1, the results of the survey show that in small companies the most often used motivators are: opportunity to express an opinion (61\%); corporate events (56\%), and salary supplements (56\%). The first two motivators more relate to the higher levels of the Maslow pyramid, i.e. expression of self-esteem and social affiliation. Opportunity to realize their ideas (44\%) is also a widely used motivator. Entrepreneurs also use the salary supplement relatively often (56\%), while additional bonuses and benefits (39\%) less. This is due to spending optimization measures in small 
companies, as entrepreneurs are often unable to afford various additional benefits to their employees, such as insurance, a car, pool or gym subscriptions, etc.

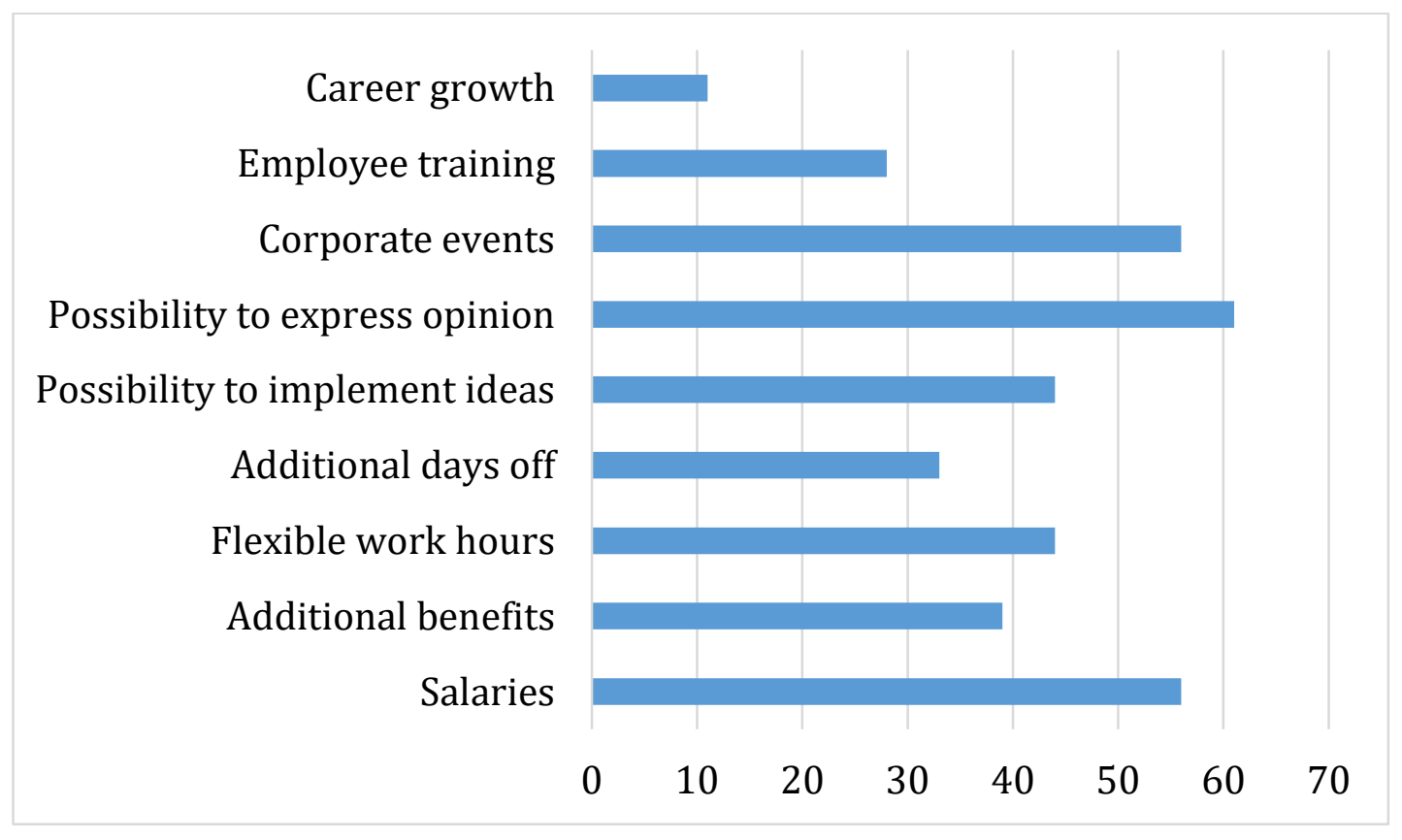

\section{Fig. 1. Motivators used in small enterprises according to the results of the entrepreneur survey, \% (compiled by the authors)}

The authors also welcome the fact that entrepreneurs use flexible working hours (44\%). This motivator is becoming an important element of current motivation, as opportunities for remote work, work-life balance, etc. are increasingly developing. If the type of business does not require precise work hours, then flexible working hours are quite an important motivator. Unfortunately, as a result of the survey, it became clear that entrepreneurs rarely used such motivators as training and career development - 28\% and $11 \%$ respectively. These results show the motivation trends of small business employees. As a result of the survey, the authors conclude that small business managers are quite passive in terms of motivation, with little interest in creating motivation. Managers focus more on monetary motivators and make little use of top-level needs of employees.

The second survey, the respondents of which were employees, was also conducted among the employees of small enterprises in Latgale region. One hundred questionnaires were distributed, 57 were returned. The questionnaires, similarly to the first survey, were distributed both electronically and in person by interviewing employees. 
Table 2. Assessment of motivational elements (employees' opinion), $\%$ (compiled by the authors)

\begin{tabular}{|l|c|c|c|}
\hline \multicolumn{1}{|c|}{ Motivator } & Motivates & $\begin{array}{c}\text { Doesn't } \\
\text { motivate }\end{array}$ & $\begin{array}{c}\text { Hard to } \\
\text { say }\end{array}$ \\
\hline Friendly, cohesive team & 84 & 12 & 4 \\
\hline Positive atmosphere in the workplace & 91 & 9 & 0 \\
\hline Adequate working hours and work schedule & 75 & 16 & 9 \\
\hline Pleasant working environment & 84 & 7 & 9 \\
\hline Career development opportunities & 41 & 48 & 11 \\
\hline Opportunities to learn & 28 & 21 & 51 \\
\hline Clear job responsibilities and outcome & 58 & 37 & 5 \\
\hline Manager's attitude & 89 & 2 & 9 \\
\hline $\begin{array}{l}\text { There is sustainability and a sense of security at } \\
\text { work }\end{array}$ & 63 & 19 & 18 \\
\hline Performance affects pay & 68 & 16 & 16 \\
\hline $\begin{array}{l}\text { Opportunity to receive evaluation and } \\
\text { recognition for a job well done }\end{array}$ & 95 & 2 & 3 \\
\hline Fear of punishment or dismissal & 42 & 49 & 9 \\
\hline Stable salary & 89 & 0 & 11 \\
\hline Adequate salary & 84 & 2 & 14 \\
\hline $\begin{array}{l}\text { It is possible to receive additional allowances } \\
\text { (bonuses, allowances for night work, etc.) }\end{array}$ & 80 & 18 & 2 \\
\hline $\begin{array}{l}\text { Possibility to receive other benefits (car, } \\
\text { telephone, insurance) }\end{array}$ & 72 & 26 & 2 \\
\hline An interesting job & 67 & 18 & 16 \\
\hline
\end{tabular}

In general, the authors conclude that workplace communication and the work environment, as well as salary and related benefits, are the most important motivators that company managers can use to motivate their employees.

Table 3. Rankings of the motivators, a comparison of opinions by employees and entrepreneurs (compiled by the authors)

\begin{tabular}{|l|c|c|}
\hline \multicolumn{1}{|c|}{ Motivator } & $\begin{array}{c}\text { Rank, } \\
\text { employers' } \\
\text { opinion }\end{array}$ & $\begin{array}{c}\text { Rank, } \\
\text { employees' } \\
\text { opinion }\end{array}$ \\
\hline Remuneration & 1 & 1 \\
\hline Social guarantees & 4 & 5 \\
\hline Working hours and schedule & 2 & 3 \\
\hline Job responsibilities and job content & 3 & 6 \\
\hline Team and atmosphere at work & 5 & 4 \\
\hline Manager and his attitude & 6 & 2 \\
\hline Career development opportunities & 9 & 9 \\
\hline Training opportunities & 8 & 8 \\
\hline Stability and sustainability & 7 & 7 \\
\hline
\end{tabular}


Entrepreneurs believe that employees are, firstly, motivated by salary, secondly, by working hours and the work schedule. In 3rd place, entrepreneurs name job responsibilities and job content. Unfortunately, social guarantees are ranked 4th, which raises some concerns that the shadow economy could occur, i.e. the gross salary of employees may not be as significant.

The entrepreneurs have ranked issues related to communication 5th and 6 th, i.e. the role of the team and the leader himself (5th and 6th place, respectively). As a result of the survey, it can be concluded that 7th, 8th and 9 th places are allocated for stability, training, and career development. Small businesses often experience change, suspension or closure in changing economic and social circumstances, so the issue of stability is sensitive enough for a small business. Although it has been shown that it is small businesses that provide the largest number of jobs.

From the point of view of employees, it can be concluded that the 1st motivator, similarly to entrepreneurs, is a salary, though, 2nd place differs in their opinion - in the employees' opinion it is a manager and his/her attitude. It is not uncommon to hear that, if quitting, employees quit the manager not the workplace - this ranking confirms it in the most direct way. According to the employees, work hours and the work schedule are rank 3rd. However, 4th place is given to the team and the atmosphere in the workplace, followed by social guarantees. The authors regret that social guarantees are not in the focus of attention by the employees, as it is a question of sustainability. Although it is subjective, because the younger and middle generation often see pensions and other negative consequences as an unattainable future.

\section{Conclusions and suggestions}

1. Summarizing and analysing various definitions of the concept of motivation, the authors conclude that the definitions are essentially similar. As a summary, the authors define motivation as an individual's conscious activity, which is focused on fulfilling personal results, goals, and needs, while ensuring the company's results and goals

2. There are differences in the perception of motivation between the employees of different generations. This means that it is important for an entrepreneur to be able to assess the difference between these generations and apply the relevant motivators.

3. Small business managers are not particularly interested in informing their employees, or it is an example of poor communication. The Labour Law stipulates that additional work must be paid for, but as the authors' empirical experience show, it is a common practice in small companies that employees perform additional duties, not only in the absence of 
another employee, but also every day. On the one hand, it is a negative trend, on the other hand, it is important for the manager of a small company to maintain an optimal level of costs and each additional employee is an additional expense.

4. Managers of companies and structural units must be able to evaluate the application of motivation theories in modern conditions, because Latvia is constantly experiencing a process of change both in the global aspect and at the national and company levels, as well as continuous development of society. When applying motivation theories in practice, it is important to take into account the personal characteristics of each individual, the degree of development, professional and intellectual level, as well as the profession, environment, economic and social conditions. Methods for motivating employees must not be used clichés in all situations and for all employees. A creative approach is needed on a case-by-case basis.

5. Small business managers should follow changes in employee motivation in search of new approaches and methods for motivation focusing on higher level needs, i.e. self-esteem and self-expression.

6. Motivation problems mostly relate to different managerial and employee priorities. Business managers should have regular discussions in formal and informal settings to learn about each individual's needs, expectations and future development opportunities. This would help to retain good employees and keep them motivated to work for the company.

\section{References}

1. Barney, B. J., Arikan, A. M. (2001). The Resource Based View: Origins and Implications. The Blackwell Handbook of Strategic Management. Oxford: WileyBlackwell.

2. Barney, J. B. (1991). Firm Resources and Sustained Competitive Advantage. Journal of Management, 17, 99- 120.

3. Bel̦čikovs, J., Praude, V. (2001). Menedžments. Rīga: Vaidelote.

4. Eriksen, B., Mikkelsen, J. (2006). Competitive Advantage and Core Competence. Towards a Competence Theory of the Firm. London: Routlege.

5. Jorfi, H., Jorfi, S., Yaacob, H. F., Yaccob, B., Shah, I. M. (2011). Relationships among Strategic Management, Strategic Behaviors, Emotional Intelligence, IT-business Strategic Alignment, Motivation, and Communication Effectiveness, International Journal of Business and Management, 6 (9), 30-37.

6. Kantāne, I. (2013). Latvijas mazo uzñēmumu vadīšanas īpatnības. Promocijas darba kopsavilkums. Rīga.

7. Macdonald, S., Assimakopoulos, D., Anderson, P. (2007). Education and Training for Innovation in SMEs: A Tale of Exploitation. International Small Business Journal, 25 (1), 77 - 95. 
8. Megginson, L. C., Byrd, M. J., Megginson, W. L. (2006). Small Business Management (5th ed.). McGraw-Hill Companies.

9. Ordynskaya, M. E., et al. (2016). Tax Incentives for Small and Medium Businesses in European Union Countries in the Crisis Period. International Journal of Economics and Financial Issues, 6, 212-218. Retrieved from http://www.econjournals.com/index.php/ijefi/article/viewFile/2554/pdf

10. Ray, G., Barney, J. B., Muhanna, W. A. (2004). Capabilities, Business Processes, and Competitive Advantage: Choosing the Dependent Variable in Empirical Tests of the Resource-based View. Strategic Management Journal, 25, 23-37.

11. Tabassi, A. A., Ramli, M., Bakar, A. H. (2012). Effects of training and motivation practices on teamwork improvement and task efficiency: The case of construction firms. International Journal of Project Management, 30, 213-224.

12. Vorončuka, I. (2009). Personāla vadība. Rīga: Latvijas Universitāte. 